JKKP : Jurnal Kesejahteraan Keluarga dan Pendidikan http://doi.org/10.21009/JKKP

DOI: doi.org/10.21009/JKKP.041.05

E-ISSN : 2597-4521

\title{
Pengembangan Multimedia Caregiver Untuk Peningkatan Pelayanan Lansia
}

\author{
Neni Rohaeni ${ }^{1}$, Mirna Purnama Ningsih ${ }^{1}$, Yoyoh Jubaedah ${ }^{1}$ \\ Email : yoju201@yahoo.co.id \\ 1)Fakultas Teknologi dan Kejuruan \\ Universitas Pendidikan Indonesia \\ J alan Setiabudi 229 Bandung
}

\begin{abstract}
ABSTRAK
Penelitian ini dilatarbelakangi oleh tuntutan kompetensi yang harus dikuasai oleh mahasiswa dan lulusan Program Studi PKK yang dirumuskan dalam Kerangka Kualifikasi Nasional Indonesia (KKNI), sebagai calon guru SMK dan konsultan keluarga serta konsultan pekerja sosial khususnya pada pendampingan lansia sebagai Caregiver. Penelitian ini bertujuan mengembangkan Multimedia Caregiver Untuk Peningkatan Pelayanan Lansia. Pemecahan masalah dilakukan dengan menggunakan pendekatan Research and Development, melalui tahapan: (1) Studi Pendahuluan, (2) Pengembangan Model dan (3) Validasi Model. Studi Pendahuluan dilakukan kegiatan: (a) Studi literatur berkaitan dengan masalah penelitian, (b) Identifikasi karakteristik multimedia Caregiver untuk Peningkatan Pelayanan lansia, (c) Merancang Story Board Multimedia Caregiver untuk Peningkatan Pelayanan Lansia.Tahap pengembangan model akan dilakukan: (a) Pembuatan Multimedia Caregiver.(b) Ujicoba Multimedia Caregiver pada Pelayanan Lansia, (c) Evaluasi dan penyempurnaan.Tahap validasi model akan dilakukan: (a) Uji validasi modelmelalui expertjudgement ahli, (b) Uji validasi model secara empirik, (c) Evaluasi dan penyempurnaan model hingga menghasilkan model final. Penelitian ini ditargetkan memiliki luaran sebagai berikut: (1) Multimedia Caregiver untuk Peningkatan Pelayanan Lansia. (2) HKI berupa Hak Cipta Video Senam Lansia
\end{abstract}

Kata Kunci : Multimedia, Caregiver, Peningkatan, Pelayanan, Lansia

\section{Development of Multimedia Caregiver to Improve he Elderly Services}

\footnotetext{
Abstract

This research supported by the demands of competence that must be by students and graduates of PKK study program. It was formulated within the Indonesia National Qualifications Framework or KKNI as teachers vocational prospective and consultants, as well as family and social worker consultants. It was particularly in the assistance for the elderly as the caregiver. This research aimed to develop a multimedia caregiver to improving services for the elderly.

The problem solving was used the research and development approach, through the: (1) the preliminary study, (2) the development model and (3) the validation model. A preliminary study conducted: (a) the literature study regarding the issue of the research, (b) the identifying characteristics of multimedia caregiver to improving services elderly, (c) the design of story board multimedia caregiver to improving services elderly.

Developmental stage model was conducted: (a) the making of multimedia caregiver, (b) the testing of multimedia caregiver to the elderly, (c) the evaluation and improvements. The validation model was conducted: (a) test validation through expert judgement the model, (b) validation in the model empirical, (c) evaluation and the model to produce a model final. This research targets
} 
to have the following output: (1) a multimedia caregiver to improve services elderly, (2) an article of the research which published in the accredited of national journal.

Key Words: Multimedia,Caregiver, Increased, Service, Elderly

\section{PENDAHULUAN}

Program Stdudi Pendidikan Kesejahteraan Keluarga Jurusan PKK FPTK UPI menyelenggarakan pendidikan mengacu pada Kerangka Kualifikasi Nasional Indonesia (KKNI) pada level 6. Pada kuaifikasi tersebut progam studi PKK diantaranya bertujuan untuk menghasilkan lulusan sebagai calon guru SMK dan tenaga ahli dibidang keilmuan dan keahlian Pelayanan Sosial. Sebagaimana dirumuskan dalam KKNI, bahwa profil lulusan program studi PKK sebagai berikut: (1) Calon Pendidik pada jalur pendidikan formal, yaitu guru SMK Bidang Keahlian Pekerjaan Sosial. (2) Pendidik pada jalur pendidikan nonformal, yaitu instruktur pada Lembaga Pelatihan Pelayanan Lansia. (3) Penyuluh Asisten Pekerja Sosial.

Profil lulusan tersebut di atas mengandung makna bahwa, mahasiswa program studi PKK harus diberikan pengalaman belajar terkait dengan keilmuan dan keahlian bidang studi serta pengalaman dalam pedagogik. Dengan demikian, lulusan program studi PKK harus menguasai keilmuan dan keahlian di bidang Pelayanan Sosial termasuk di dalamnya Pelayanan Lansia sebagai Pelayanan masyarakat (stakeholders) dan juga mampu mengajarkan keilmuan dan keahlian tersebut kepada peserta didik di SMK atau pada lembaga pendidikan non formal.

Dalam implementasi mata kuliah Keilmuan dan Keahlian Pelayanan Sosial, khususnya Pendidikan Caregiver diperlukan media pembelajaran yang dapat memotivasi mahasiswa dalam belajar dan meningkatkan kompetensi keahlian dalam memberikan pelayanan kepada lansia. Media yang digunakan seyogianya menjadi perantara yang mampu memperjelas materi perkuliahan, khususnya untuk materi pada kompetensi keahlian Caregiver karena tidak memungkinkan untuk menghadirkan lansia ke kelas. Kondisi ini dapat diatasi melalui kunjungan langsung ke lembaga sosial atau melalui multimedia yang dapat menggambarkan kegiatan pelayanan lansia sebagai pelayanan sosial. Pandangan ini sejalan dengan konsep multimedia yang dirujuk dari Zakir, S. (2014), sebagai berikut: "Multimedia adalah kombinasi dari tiga elemen, yaitu: suara, gambar, dan teks sebagai alat yang dapat menciptakan presentasi yang dinamis dan interaktif yang mengkombinasikan teks, grafik, animasi, audio, dan gambar video".

Penggunaan multimedia dalam pembelajaran adalah sebagai alternatif upaya yang dapat dilakukan oleh dosen, yang diharapkan dapat memberikan pengalaman belajar yang inovatif dan lebih mengarah pada kontekstual dunia kerja di bidangnya. Dengan demikian, mahasiswa tidak hanya memperoleh pengalaman belajar di bidang keilmuan dan keahliannya tetapi mendapatkan pengalaman pula di dalam memilih dan menggunakan media pembelajaran yang inovatif.

Dari fenomena di atas,maka peneliti tertarik untuk melakukan penelitian yang berkaitan dengan pengembangan Multimedia Caregiver untuk Peningkatan Pelayanan Lansia.

\section{METODE PENELITIAN}

Pendekatan penelitian yang digunakan untuk menjawab masalah penelitian yang telah dirumuskan dalam penelitian ini adalah Research and Development (R\&D). Langkah penelitian Research and Development dalam penelitian ini meliputi tiga tahap, yaitu : (1) Studi Pendahuluan, (2) Pengembangan Model dan (3) Uji Model (Validasi Model). (Disarikan dari Sukmadinata: 2005).

Penelitian dilakukan pada pembelajaran Pelayanan Lansia Program Studi PKK di Universitas Pendidikan Indonesia, dengan subjek penelitian terdiri dari mahasiswa dan Dosen pengampu mata kuliah Pelayanan Lansia. 


\section{HASIL DAN PEMBAHASAN}

\section{Rancangan Multimedia Caregiver untuk Pelayanan Lansia}

Observasi yang dilakukan berupa participant observation, yaitu peneliti terlibat langsung dalam kegiatan pendampingan lansia dengan menggunakan video pembelajaran oleh caregiver.

Multimedia Caregiver sebagai media pembelajaran inovatif sudah banyak digunakan dalam pembelajaran baik di sekolah maupun di perguruan tinggi, karena media tersebut menarik, sehingga dapat memberikan motivasi belajar kepada pebelajar. Multimedia merupakan perpaduan dari beberapa elemen informasi yang dapat berupa teks, gambar, suara, animasi, dan video.

Dalam pembuatan multimedia caregiver untuk pelayanan lansia ini, dilakukan melalui 2 tahap yakni :

\section{a. Penulisan naskah}

Naskah yang menjadi narasi dipilih dari materi pembelajaran tentang Activity of Daily Living/ ADL, yaitu lima macam kegiatan sehari-hari diantaranya makan, mandi, berpakaian, mobilitas dan toileting. Video tersebut ditampilkan dalam kegiatan indoor dan outdoor.

b. Storyboard dikembangkan dengan memperhatikan beberapa petunjuk sebagai berikut:

1) Menetapkan jenis visual yang digunakan untuk mendukung isi pelajaran dan mulai membuat sketsanya.

2) Beberapa bagian ada yang diperankan dengan audio dalam paket program. Audio yang dipilih ada dalam bentuk: diam, sound effect khusus, suara latar belakang, musik dan narasi.

3) Seluruh materi yang berkaitan dengan kegiatan lansia, yaitu kegiatansehari-hari diantaranya makan, mandi, berpakaian, mobilitas dan toileting sudah tercakup dalam storyboard. Sebelum masuk pada materi, diawali dengan kegiatan introduction dan highlight tetang tujuan dari pembuatan video dan cuplikan - cuplikan isi video.

4) Mereviu storyboard sambil mengecek hal-hal berikut:Semua audio dan grafik cocok dengan teks, pengantar dan pendahuluan menampilkan sesuatu yang dapat menarik perhatian, informasi penting telah dicakup, urutan interaktif telah digabungkan, narasi singkat padat, program mendukung latihan-latihan, alur dan organisasi program mudah diikuti dan dimengerti, kumpulkan dan paparkan semua storyboard sehingga dapat terlihat sekaligus, kumpulkan anggota tim produksi untuk mereviu dan mengeritik storyboard, catat semua komentar, kritik, dan saran-saran

5) Revisi untuk persiapan akhir sebelum memulai produksi.

\section{Validasi Media Pembelajaran oleh Expert J udgement}

Setelah video pembelajaran dibuat dengan mengacu pada storyboard yang telah divalidasi oleh akhli konten, maka selanjutnya media divalidasi oleh ahli media.

Data dari hasil validasi media pembelajaran berupa video yng dilakukan oleh akhli media, terdiri dari 4 indikator, yaitu format, isi, bahasa dan durasi. Pada indkcator format mendapatkan rata-rata capaian sebesar $89 \%$ termasuk pada kriteria sangat layak. Indikator isi mendapatkan rata-rata capaian sebesar $87,5 \%$ termasuk pada kriteria sangat layak. Indikator bahasa mendapatkan rata-rata capaian sebesar $81,25 \%$ termasuk pada kriteria sangat layak. Indikator terakhir yaitu durasi mendapatkan rata-rata capaian sebesar $87,5 \%$ termasuk pada kriteria sangat layak. Secara keseluruhan media pembelajaran berupa video yang telah dibuat tersebut mencapai rata-rata sebesar $86,3 \%$, sehingga dapat dikatakan bahwa video pembelajaran yang telah dibuat menurut akhlimedia pembelajaran dinyatakan layak untuk selanjutnya dapat diimplementasikan dalam perkuliahan Pelayanan lansia.

Validator memberikan saran dan masukan yang berkaitan dengan indicator suara.Musi pengiring yang dipergunakan terlalu keras atau dominan, sehingga suara penjelasan yang disampaikan kurang terdengar, sedangkan mengenai indicator isi, bahasa dan durasi dinyatakan sudah cukup.Saran dan masukkan yang telah disampaikan validator djadikan bahan evaluasi untuk perbaikan media yang sudah dibuat. 
Pembahasan hasil penelitian merupakan suatu kajian deskripsi hasil penelitian dengan dasar teori yang ada.Data yang diperoleh melalui tindakan validasi video sebagai media pembelajaranuntuk peningkatan pelayanan lasia oleh validator expert judgment.

Pengembangan multimedia caregiver untuk peningkatan pelayanan lansia diawali dengan proses perancangan melalui kegiatan identifikasi kebutuhan media pembelajaran yang dapat memudahkan para mahasiswa unntuk memahami konsep caregiver untuk peningkatan pelayanan lansia. Media yang dibutuhkan untuk peningkatan pelayanan lansia yaitu media, dalam bentuk video. Hal tersebut dikarenakan ketika proses pembelajaran tidak memungkinkan untuk menghadirkan lansia ke kelas. Untuk itu sesuai dengan pendapat Heinich (Rusman, 2012) mengemukakan bahwa : Tampilan video bergerak, video dalam proses pembelajaran menampilkan gerakan-gerakan yang dapat memaparkan materi pembelajaran secara lebih nyata sehingga penampilan lebih dinamis. Hal ini lebih membuat video lebih menarik dan menguntungkan dari media lain.

Materi yang diangkat dalam pembuatan video ini adalah materi yang berkaitan dengan kegiatan lansia, yaitu kegiatan sehari-hari. Aktifitas sehari-hari yang harus dilakukan oleh lansia ada lima macam diantaranya makan, mandi, berpakaian, mobilitas dan toieting (Brunner \& Suddart, 2001). Untuk memenuhi kebutuhan lansia diperlukan pengetahuan atau kognitif dan sikap yang dapat mempengaruhi perilaku lansia dalam kemandirian pemenuhan kebutuhan Activity Of Daily Living ( $A D L)$.Lansia dalam kehidupannya harus terpenuhi baik kebutuhan fisik maupun psikhis sesuai dengan kebutuhan dan kondisi lansia, karena ada lansia yang pasif dan lansia aktif.Pada kondisi tersebut lansia butuh bantuan dalam beraktifitas, baik bantuan ringan maupun bantuan yang sifatnya sangat tergantung dalam hal ini tergantung pada orang yang merawatnya (caregiver).Rancangan materi yang dibuat diantaranya mengacu pada kegiatan fisik, misalnya melalui kegiatan berolah raga ringan.

Langkah-langkah mempertahankan ADL pada lansia :

1. Latihan kepala dan leher

a. Lihat keatap kemudian menunduk sampai dagu ke dada.

b. Putar kepala dengan melihat bahu sebelah kanan lalu sebelah kiri. c. Miringkan kepala ke bahu sebelah kanan lalu kesebelah kiri.

2. Latihan bahu dan lengan

a. Angkat kedua bahu ke atas mendekati telinga kemudian turunkan kembali perlahan-lahan

b. Tepukan kedua telapak tangan dan renggangkan lengan kedepan lurus dengan bahu. Pertahankan bahu tetap lurus dan kedua tangan bertepuk kemudian angkat lengan keatas kepala.

c. Satu tangan menyentuh bagian belakang dari leher kemudian raihlah punggung sejauh mungkin yang dapat dicapai. Bergantian tangan kanandan kiri.

d. Letakan tangan di punggung kemudian coba meraih keatas sedapatnya.

3. Latihan tangan

a. Letakan telapak tangan diatas meja. Lebarkan jari-jarinya dan tekan ke meja.

b. Baliklah telapak tangan. Tariklah ibu jari melintasi permukaan telapak tangan untuk menyentuh jari kelingking.Kemudian tarik kembali.Lanjutkan dengan menyentuh tiap-tiap jari dengan ibu jari dan kemudian setelah menyentuh tiap jari.

c. Kepalkan tangan sekuatnya kemudian renggangkan jari-jari selurus mungkin.

4. Latihan punggung

a. Dengan tangan disamping bengkokan badan kesatu sisi kemudian kesisi yang lain.

b. Letakan tangan dipinggang dan tekan kedua kaki, putar tubuh dengan melihat bahu kekiri dan kekanan. 
c. Tepukan kedua tangan dibelakang dan regangkan kedua bahu ke belakang.

5. Latihan paha

a. Latihan ini dapat dilakukan dengan berdiri tegak dan memegang sandaran kursi atau dengan posisi tiduran.

b. Lipat satu lutut sampai pada dada dimana kaki yang lain tetap lurus, dan tahan beberapa waktu.

c. Duduklah dengan kedua kaki lurus kedepan. Tekankan kedua lutut pada tempat tidur hingga bagian belakang lutut menyentuh tempat tidur.

d. Pertahankan kaki lurus tanpa membengkokan lutut, kemudian tarik telapak kaki kearah kita dan regangkan kembali.

e. Tekuk dan regangkan jari-jari kaki tanpa menggerakan lutut.

f. Pertahankan lutut tetap lurus, putar telapak kaki kedalam sehingga permukaannya saling bertemu kemudian kembali lagi.

g. Berdiri dengan kaki lurus dan berpegangan pada bagian belakang kursi. Angkat tumit tinggi-tinggi kemudian putarkan.

6. Latihan pernafasan

Duduklah di kursi dengan punggung bersandar dan bahu relaks.Letakkan kedua telapak tangan pada tulang rusuk.Tarik nafas dalam-dalam maka terasa dada mengambang.Sekarang keluarkan nafas perlahan-lahan sedapatnya. Terasa tangan akan menutup kembali.

7. Latihan muka

a. Kerutkan muka sedapatnya kemudian tarik alis keatas.

b. Tutup mata kuat-kuat, kemudian buka lebar-lebar.

c. Kembangkan pipi keluar sebisanya. Kemudian isap kedalam.

d. Tarik bibir kebelakang sedapatnya, kemudian ciutkan dan bersiul.

Validasi storyboard yang dilakukan berfokus pada uji kelayakan konten atau materi tersebut ti atas yang akan dijadikan materi dalam pembuatan video pembelajaran. Indikator pada uji kelayakan storyboard yaitu meliputi kelayakan dari topik narasi dan adegan.

Penilaian pada indikator topik meliputi aspek-aspek kesesuaian kompetensi dasar yang dijadikan sebagai tujuan pembelajaran yaitu topik pada perancangan media video relevan dengan sasaran pembelajaran. Dalam implementasi mata kuliah Keilmuan dan Keahlian Peayanan Sosial, khususnya Pendidikan Caregiver diperlukan media pembelajaran yang dapat memotivasi mahasiswa dalam belajar dan meningkatkan kompetensi keahlian dalam memberikan pelayanan kepada lansia. Media yang digunakan seyogianya menjadi perantara yang mampu memperjelas materi perkuliahan, khususnya untuk materi pada kompetensi keahlian Caregiver karena tidak memungkinkan untuk menghadirkan lansia ke kelas. Kondisi ini dapat diatasi melalui kunjungan langsung ke lembaga sosial atau melalui multimedia yang dapat menggambarkan kegiatan pelayanan lansia sebagai pelayanan sosial. Pandangan ini sejalan dengan konsep multimedia yang dirujuk dari Zakir, S. (2014), sebagai berikut: "Multimedia adalah kombinasi dari tiga elemen, yaitu: suara, gambar, dan teks sebagai alat yang dapat menciptakan presentasi yang dinamis dan interaktif yang mengkombinasikan teks, grafik, animasi, audio, dan gambar video".

Penggunaan multimedia dalam pembelajaran adalah sebagai alternatif upaya yang dapat dilakukan oleh dosen, yang diharapkan dapat memberikan pengalaman belajar yang inovatif dan lebih mengarah pada kontekstual dunia kerja di bidangnya. Dengan demikian, mahasiswa tidak hanya memperoleh pengalaman belajar di bidang keilmuan dan keahliannya tetapi mendapatkan pengalaman pula di dalam memilih dan menggunakan media pembelajaran yang inovatif. Pada aspek topik mencapat capaian rata-rata sangat layak. Capaian tersebut sesuai dengan pendapat yang dikemukan Sanjaya (2014) yang mengatakan bahwa dalam perancangan media pembelajaran, perumusan tujuan pembelajaran yang jelas dan terstruktur merupakan aspek 
penting untuk menentukan keberhasilan mahasiswa dalam melakukan pembelajaran.

Penilaian pada indikator narasi meliputi aspek narasi yang dapat menggambarkan inti dari video pembelajaran yaitu bahasa narasi komunikatif dan sesuai dengan materi pokok. Indikator narasi mencapai rata-rata sangat layak. Hal ini didukung oleh pendapat Sadirman Arief (2014) menyatakan bahwa narasi pada video harus disesuaikan dengan adegan dan bahasa yang digunakan haruslan bahasa lisan bukan bahasa tulisan.Pada kondisi tersebut lansia butuh bantuan dalam beraktifitas, sehingga melalui tayangan video dapat memudahkan caregiver dalam membimbing para lansia untuk beraktifitas baik bantuan ringan maupun bantuan yang sifatnya sangat tergantung.

Indikator adegan mendapatkan rata-rata capaian sangat layak, capaian tersebut sesuai dengan pernyataan yang dikemukakan Sadirman Arief (2014) bahwa apa yang tergambar harus cukup penting dan cocok untuk hal yang sedang dipelajari atau masalah yang sedang dihadapi. Indikator adegan sesuai dengan prosedur pembuatan video pembelajaran.Multimedia yang dihasilkan sebagai media pendampingan bagi Caregiver di dalam memberikan pelayanan kepada lansia, dapat meningkatkan pelayanan kepada lansia. Multimedia ini berupa video pendampingan lansia, yang dapat digunakan pada pembelajaran Pelayanan Lansia atau Peayanan Sosial baik pada pendidikan formal, non formal maupun pada lembaga sosial.

\section{KESIMPULAN}

1. Multimedia Caregiver untuk Peningkatan Pelayanan Lansia dirancang sesuai dengan kebutuhan mata kuiah Pelayanan Anak dan Lansia dalam meningkatkan proses pembelajaran dan kompetensi mahasiswa.

2. Multimedia Caregiver yang diimplementasikan pada pembelajaran Pelayanan Anak dan Lansia dapat meningkatkan kompetensi mahasiswa dalam pelayanan lansia.

3. Multimedia Caregiver layak untuk diimplementasikan pada pelayanan lansia baik pada pendidikan formal, non formal maupun in formal, karena sudah sesuai dengan karakteristik dan kebuhan lansia.

\section{DAFTAR PUSTAKA}

Arsyad, A. 2004. Media Pembelajaran. PT. Raja Grafindo Persada. Jakarta.

Cooper, James M. 1990. Classroom Teaching Skills. D.C. Healt and Company. Canada

Jubaedah, Y., dkk. 2007. Pengembangan Model Pembelajaran Berbasis Multimedia Untuk

Peningkatan Kompetensi Peserta Didik Sesuai Standar Kompetensi Nasional di SMK.

Universitas Pendidikan Indonesia. Bandung

Khasanah, U. 2012. Kontribusi Penguasaan Pengetahuan Pelayanan Usia Lanjut Terhadap

Kesiapan Menjadi Care Giver. Jurusan PKK FPTK UPI. Bandung.

Pratama, Y.I. 2011. Definisi Care Giver. Tersedia [online] http://www.facebook.com/home.php?sk=group $194558470580801 \& v i e w=d o c \& i d=19475844$ 3894137 (21 Februari 2014).

Sadiman, Arief dkk.2014. Media Pendidikan Pengertian, Pengembangan dan Pemanfaaatannya. Rajawali Press. Jakarta.

Sanjaya, Wina. 2014. Media komunikasi Pembelajaran. Kencana. Jakarta.

Sukmadinata, N.S. 2005. Metode Penelitian Pendidikan. PT Remaja Rosdakarya. Bandung. Universitas Pendidikan Indonesia. 2013. Rambu-Rambu Pengembangan Kurikulum UPI. Bandung.

Zakir, S. 2014. Modul Pembelajaran Berbasis Multimedia. Tersedia [online] http://www.stainbukittinggi.ac.id/it/index.php/artikel/146-modulpem. (21Februari 2014). 